\title{
Late Quaternary landscapes in Central Australia: sedimentary history and palaeoecology of Puritjarra rock shelter
}

\author{
M. A. SMITH* \\ Centre for Historical Research, National Museum of Australia, Canberra, ACT, Australia
}

Smith, M. A. 2009. Late Quaternary landscapes in Central Australia: sedimentary history and palaeoecology of Puritjarra rock shelter. J. Quaternary Sci., Vol. 24 pp. 747-760. ISSN 0267-8179.

Received 1 August 2008; Revised 18 November 2008; Accepted 19 November 2008

\begin{abstract}
Puritjarra rock shelter provides a long record of late Quaternary vegetation in the Australian arid zone. Analysis of the sedimentary history of this rock shelter is combined with reanalysis of charcoal and phytolith records to provide a first-order picture of changing landscapes in western Central Australia. These show a landscape responding to increasing aridity from $45 \mathrm{ka}$ with deflation of clay-rich red palaeosols $(<45 \mathrm{ka})$ and sharp declines in grassland and other vegetation at 40-36 ka, and at the beginning of the Last Glacial Maximum (LGM) $(24 \mathrm{ka})$. Vegetation in the catchment of the rock shelter recovered after $15 \mathrm{ka}$ with expansion of both acacia woodland and spinifex grasslands, registering stronger summer rainfall in the interior of the continent. By $8.3 \mathrm{ka}$ re-vegetation of local palaeosols and dunes had choked off sediment supply to the rock shelter and the character of the sediments changed abruptly. Poaceae values peaked at $5.8 \mathrm{ka}$, suggesting the early-mid Holocene climatic optimum in Central Australia is bracketed between 8.3 and $5.8 \mathrm{ka}$. Local vegetation was disrupted in the late Holocene with a sharp decline in Poaceae at $3.8 \mathrm{ka}$, coinciding with an abrupt intensification of ENSO. Local grasslands recovered over the next two millennia and by $1.5 \mathrm{ka}$ the modern vegetation appears to have become established. Copyright (C) 2009 John Wiley \& Sons, Ltd.
\end{abstract}

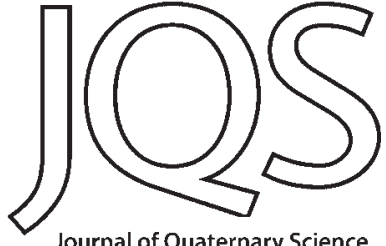

Journal of Quaternary Science

KEYWORDS: Australian arid zone; late Quaternary; landscape history; site formation; palaeoecology.

\section{Introduction}

One of the most fundamental gaps in current understandings of desert prehistory is the lack of fine-grained data on regional palaeoecology. In the extensive spinifex and sand hill habitats of central and western Australia, there are few long records of late Quaternary vegetation or paired archaeological-palaeoecological records (Hesse et al., 2004: 99). Elsewhere in central Australia, a range of palaeoenvironmental data has come from linear and source-bordering dunes (Nanson et al., 1992, 1995; Twidale et al., 2001; Hollands et al., 2006; Fitzsimmons et al., 2007a), playas, evaporites and groundwater systems (Chen et al., 1991, 1993; English et al., 2001), and floodplain and palaeoflood deposits (Pickup et al., 1988; Patton et al., 1993; Tooth, 1997; Bourke, 1998) but these have been used principally as proxies for palaeoclimate, rather than integrated reconstructions of late Quaternary landscapes. In contrast, the growing body of archaeological research in Australia's arid zone has sharpened the need for fine-grained reconstruction of regional palaeoenvironments, as a prerequisite for evaluating patterns of humanenvironment interaction, resource use and settlement histories

* Correspondence to: M. A. Smith, Centre for Historical Research, National Museum of Australia, GPO Box 1901, Canberra ACT 2601, Australia.

E-mail: m.smith@nma.gov.au
(Smith, 1989, 2005b; Veth, 1993, 1995; Hiscock, 1994; Thorley, 1998; Ross, 2003; Hiscock and Wallis, 2005).

Puritjarra rock shelter in western Central Australia (Smith, 1987) has produced one of the few direct records of late Quaternary vegetation in the heart of the desert - and the only one paired with an archaeological record. This paper (the final in a series of reports on Puritjarra) integrates data on the sedimentary history of Puritjarra with a reanalysis of the charcoal and phytolith records, to provide a first-order picture of changing landscapes in western Central Australia. A related aim is to encourage research into rock shelters as archives of palaeoenvironmental data (Farrand, 2001; Woodward and Goldberg, 2001). Occupation debris from human use of a rock shelter is commonly intercalated within a sedimentary sequence that may itself have a complex history. With few exceptions (e.g. Wallis, 2001), this type of evidence has not been systematically exploited in Australia since the 1970s. However, in Australian deserts, the scarcity of other palaeoecological records underscores the potential of Late Pleistocene deposits at archaeological sites, such as Kulpi Mara (Thorley, 1998) and Serpent's Glen (O'Connor et al., 1998), for this type of research.

As the only long record of palaeovegetation from Central Australia, Puritjarra is also the key to integrating other records of Quaternary history in the Amadeus basin, a necessary step to reconstruct regional palaeoenvironments in any detail. Vegetation not only registers the effects of climate change directly, 
but also is important in mediating many landscape responses to shifts in climate, and is probably the most important indicator of the likely productivity of the country for Late Pleistocene and Holocene hunter-gatherer populations.

\section{The site and its setting}

Puritjarra rock shelter is one of several sites with long ( $>20 \mathrm{ka}$ ) archaeological sequences in the interior of the Australian arid zone (Veth, 1995; O'Connor et al., 1998; Thorley, 1998; Smith, 2005b). Archaeological excavations between 1986 and 1990 showed that the sedimentary history of the site spans the last $100 \mathrm{ka}$, with most evidence of human occupation falling within the last $35 \mathrm{ka}$. Published studies deal with the ${ }^{14} \mathrm{C}$ and luminescence chronology of the site (Smith et al., 1997, 2001; Prescott et al., 2007), occupation history and flaked stone artefacts (Smith, 2006), grindstones and plant use (Smith, 2004), rock art (Rosenfeld and Smith, 2002), ochres (Smith et al., 1998a), post-contact Aboriginal history of the rock shelter (Smith, 2005a), as well as palaeoecological research on the charcoals (Smith et al., 1995) and phytoliths (Bowdery, 1995, 1998).

\section{Regional setting}

Puritjarra $\left(23^{\circ} 50^{\prime} \mathrm{S}, 130^{\circ} 51^{\prime} \mathrm{E}\right)$ is situated in the Cleland Hills, $60 \mathrm{~km}$ west of the MacDonnell Ranges and on the northern rim of the Amadeus basin (Fig. 1). The area is a transitional zone between ranges and desert lowlands, and biogeographically is part of the Great Sandy Desert (Thackway and Cresswell, 1995). Mean modern rainfall is $\sim 250 \mathrm{mma}^{-1}$ at the nearest stations (Tempe Downs: $249.7 \mathrm{~mm}$; Alice Springs: $257.8 \mathrm{~mm}$ ), with a wide inter-annual range $(41-980 \mathrm{~mm})$. This falls predominantly in summer as the site is near the modern limit of summer monsoon rainfall. Vegetation in the vicinity of Puritjarra is representative of the major vegetation formations in Central Australia today, including mulga woodland, dune field and hummock grassland habitats, and flora characteristic of rocky hills and escarpments in the region (see Jessop, 1981; Perry and Lazarides, 1962).
Rock shelter morphology and geomorphic setting

Morphologically the site is an unusually large joint-controlled rock shelter formed in Ordovician/Devonian Mereenie sandstone (Fig. 2). Cross-bedding in the Mereenie sandstone forming the vaulted roof has created an area of structural weakness in the centre of the rock shelter. This has periodically shed large blocks of sandstone, resulting in a cone of roof fall, now partly buried by sediments, dividing the shelter floor into northern and southern sectors (Fig. 3).

The rock shelter forms part of a small (15 $\mathrm{m}$ high) sandstone escarpment and faces out onto sand plain and dune field (Fig. 2(B)). Behind and above the shelter there is an extensive low sandstone plateau, marked by conical 'beehive' hills and deep joint lines. Because it forms a shell-like structure facing into the prevailing south-east wind the shelter is well positioned to receive aeolian sediments from the adjacent dune field (Fig. 4). A low sand mound aligned with the trend of local longitudinal sand ridges $\left(248^{\circ}\right)$ has formed across the mouth of the shelter. Where linear dunes meet the Cleland Hills escarpment they often form windward accumulations, with a distinct gap where increased turbulence has swept the escarpment clear of sand (Mabbutt 1977: 246). Although local dune crests are active today, similar turbulence appears to have prevented the shelter from being choked by aeolian sand.

The morphology of the shelter and adjacent escarpment also prevents any significant fluvial or colluvial input to the deposit today, and this appears to have been the case throughout the life of the shelter. The floor of the shelter receives minor slope wash along the drip line but is sheltered from direct rainfall or vertical percolation of water through the profile. After extreme rainfall events (as observed in May 1988), there is lateral infiltration of moisture into the deposit from outside the shelter, localised moisture beneath fissures in the sandstone, and minor ponding in a topographic low on the northern edge of the drip line (Fig. 3).

\section{Materials and methods}

\section{Quantitative data collected during excavation}

Figure 3 shows the position of excavation trenches at Puritjarra, including N25 (outside the rock shelter) and ST5 (against the rear wall). During the excavations, all sediments were weighed

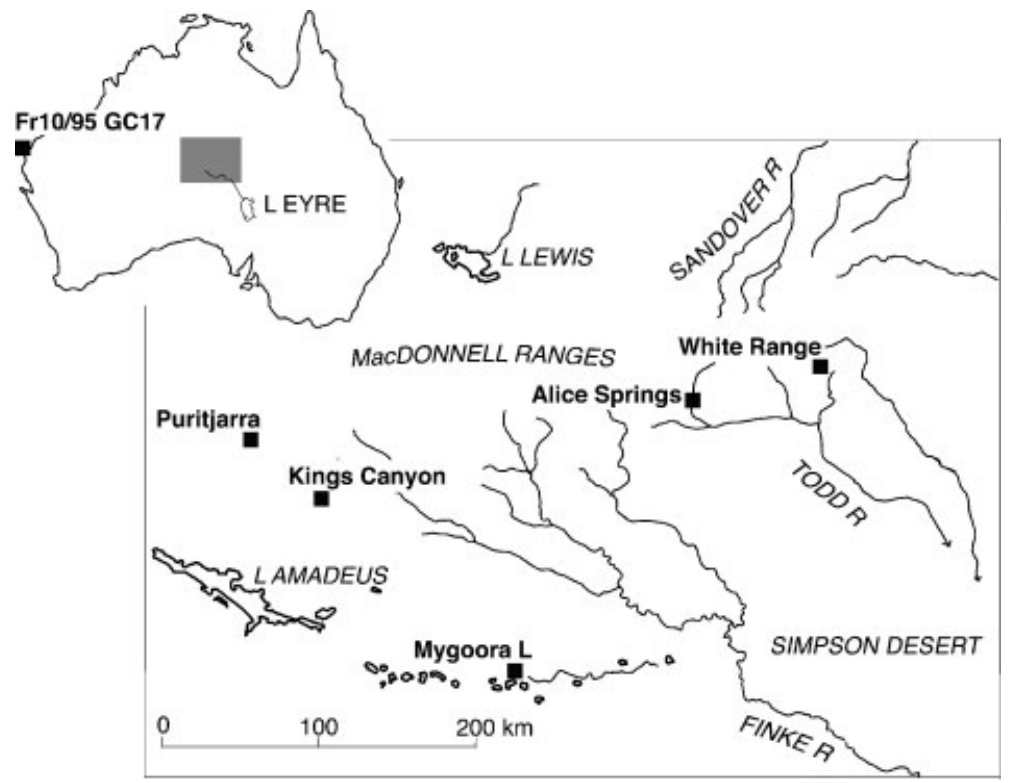

Figure 1 Central Australia, showing places mentioned in the text 

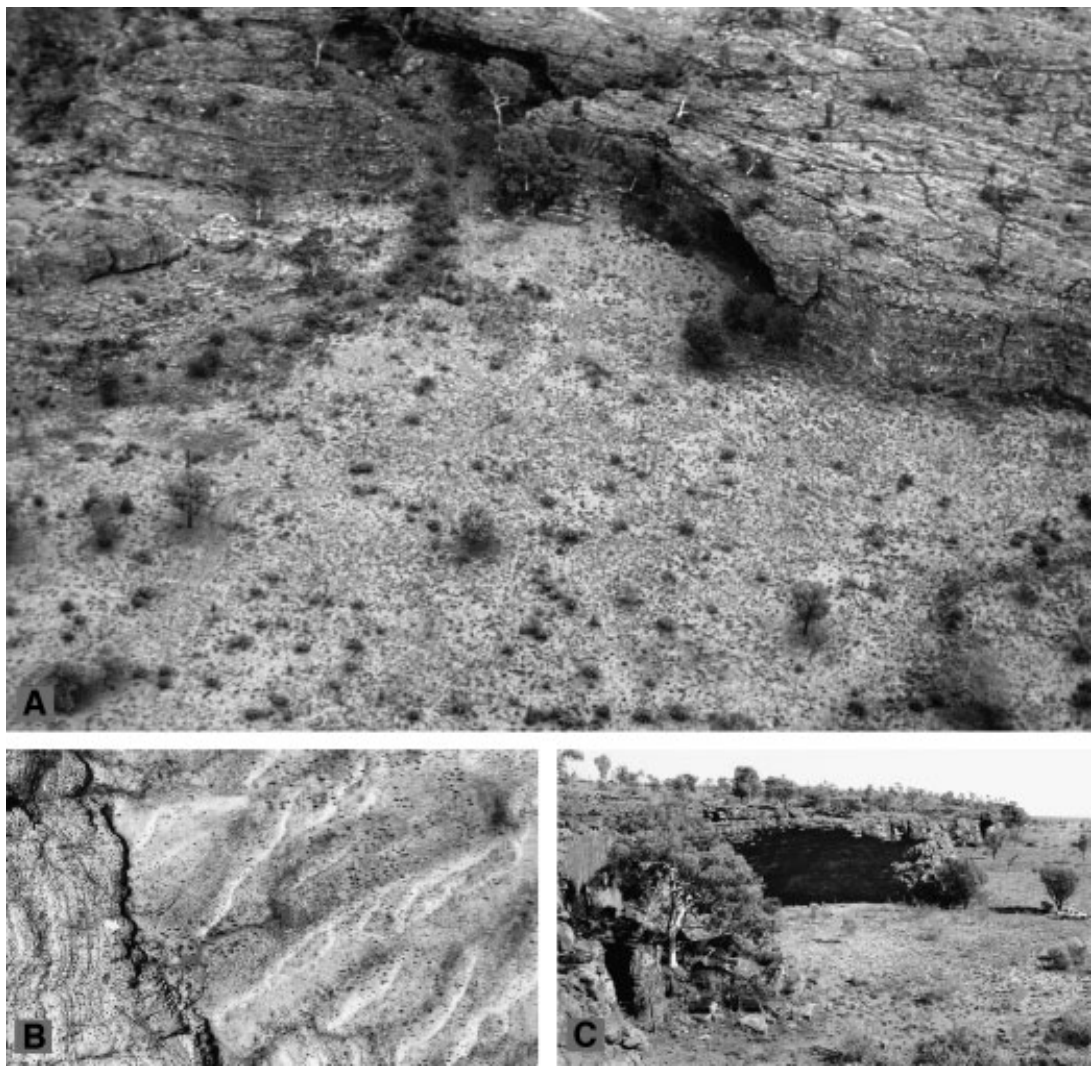

Figure 2 The geomorphic setting of Puritjarra rock shelter. (A) Oblique aerial view. (B) Aerial photograph showing the position of the rock shelter (arrow) in relation to sandridges and dune corridors. Width of image is approx. $2.5 \mathrm{~km}$. CAG 2767/946, November 1984, () Commonwealth of Australia, Geoscience Australia (1984), reproduced with permission. (C) The rock shelter, looking north. Photographs (A) and (C): M. A. Smith

and screened through $3 \mathrm{~mm}$ and $6 \mathrm{~mm}$ sieves. This facilitated collection of quantitative data for each excavation unit, allowing the proportion of fine sediments $(<3 \mathrm{~mm})$, rock fragments, charcoal, bone and stone artefacts in the deposits to be calculated across the site. The following field-size classes were used: rocks $(>50 \mathrm{~mm}$ in any dimension); coarse rock fragments $(6-50 \mathrm{~mm})$; fine rock fragments $(3-6 \mathrm{~mm})$. This provides a rough granulometry for comparison with grain-size and thin-section analyses.

\section{Grain-size analyses}

Grain-size analyses of the fine sediments (sands, silts and clays) followed Folk (1980) and Lewis (1984). Bulk (unsieved) samples were split into 30-60 g subsamples using a riffle box. The samples were disaggregated before analysis using dispersant $(10 \mathrm{~mL} 10 \%$ sodium tripolyphosphate and $5 \mathrm{~mL} 5 \%$ sodium hydroxide), agitation and ultrasonic cleaning. The sand fraction $(-1$ to $4 \phi)$ was then separated by wet sieving using a

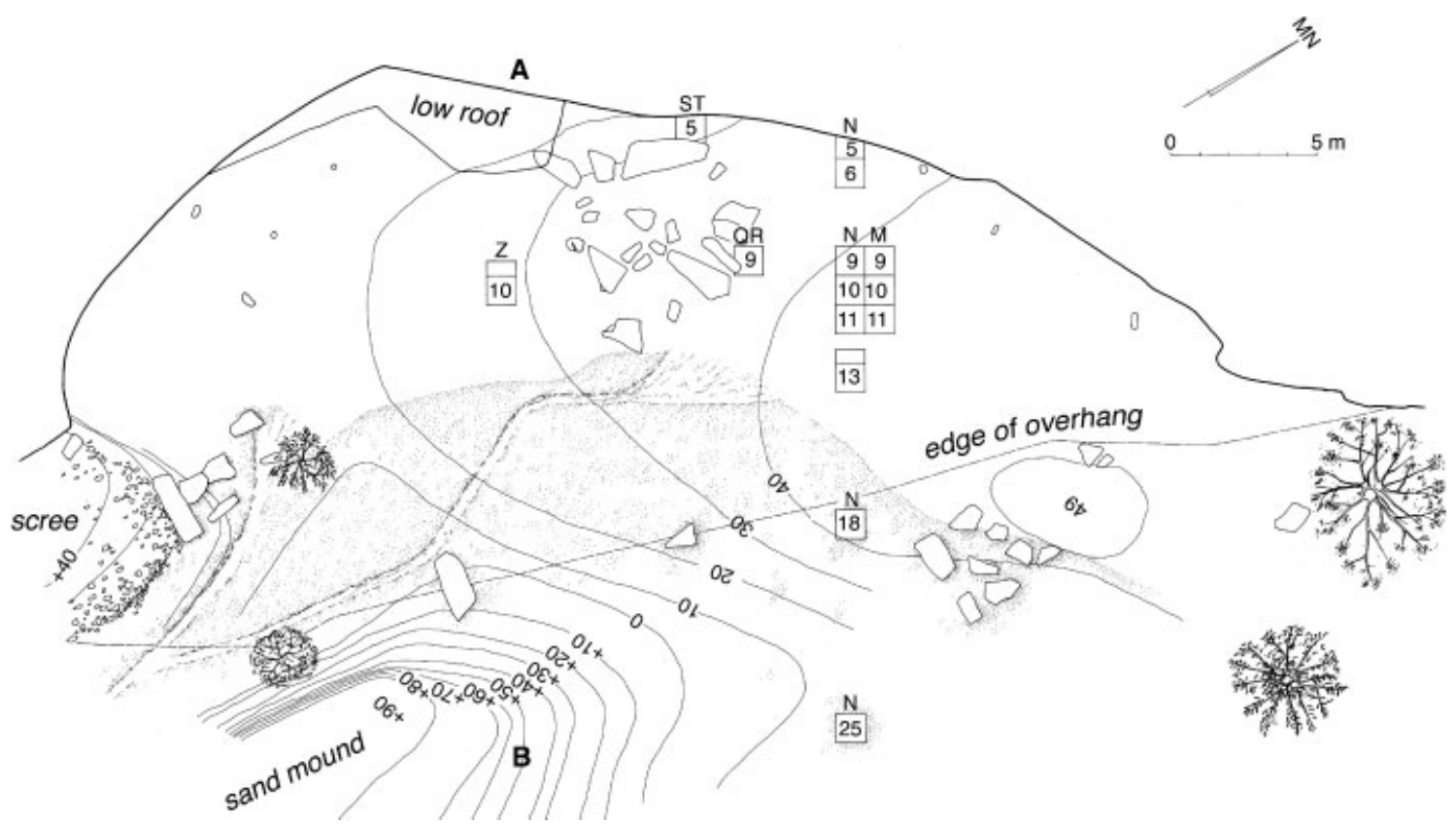

Figure 3 Plan of Puritjarra rock shelter, showing modern floor contours and layout of excavation trenches. Contour interval is $10 \mathrm{~cm}$. Heights are relative to site datum 


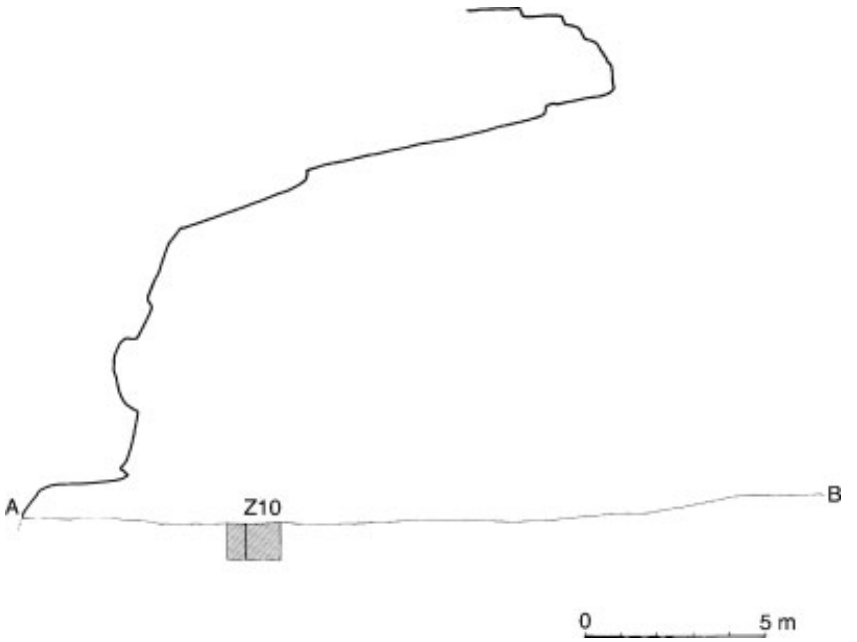

Figure 4 Profile of the rock shelter (cross-section through A and B in Fig. 3)

$4 \phi$ mesh $(62.5 \mu \mathrm{m})$ granulometric sieve and inspected under a microscope to check that clay skins and aggregates were completely disaggregated. Sand class percentages at $0.25 \phi$ intervals were obtained using a nest of standard granulometric sieves on a mechanical shaker for $15 \mathrm{~min}$. Silt and clay percentages were determined by optical transmission using a HORIBA CAPA-300 analyser. The $9 \phi(2 \mu \mathrm{m})$ boundary between silt and clay fractions was used throughout (Folk, 1980).
Thin sections and grain mounts

The micromorphology of grain and soil aggregates was examined using oriented blocks of sediment from a column in N13 and from key points on other sections. These were vacuum impregnated with polyester resin and 25-30 $\mu \mathrm{m}$ thin sections were prepared. Where blocks of sediment were impossible to extract intact, grain mounts from loose-grain samples were used to inspect the micromorphology of grains and soil aggregates. Thin sections and grain mounts were examined under plane-polarised light (PPL) and cross-polarised light (XPL) using a petrological microscope.

\section{Phytoliths and charcoals}

Bowdery took samples for phytolith analysis during the 1988 field season from three stratigraphic columns at Puritjarra (Bowdery, 1998), but most analytical attention has focused on the column from N11 in the central part of the rock shelter (shown as P1 in Fig. 5). Details of sampling and preparation are given in Bowdery (1995: Appendix 4.1). A taxonomic framework developed by Bowdery (1995) for the Australian arid zone was used to classify and group the phytoliths. Detrital charcoal in the Puritjarra sediments was systematically collected during the excavations. Sampling and preparation methods are described in Smith et al. (1995). A framework for identifying Central Australian charcoals is set out in Smith et al. (1998b).

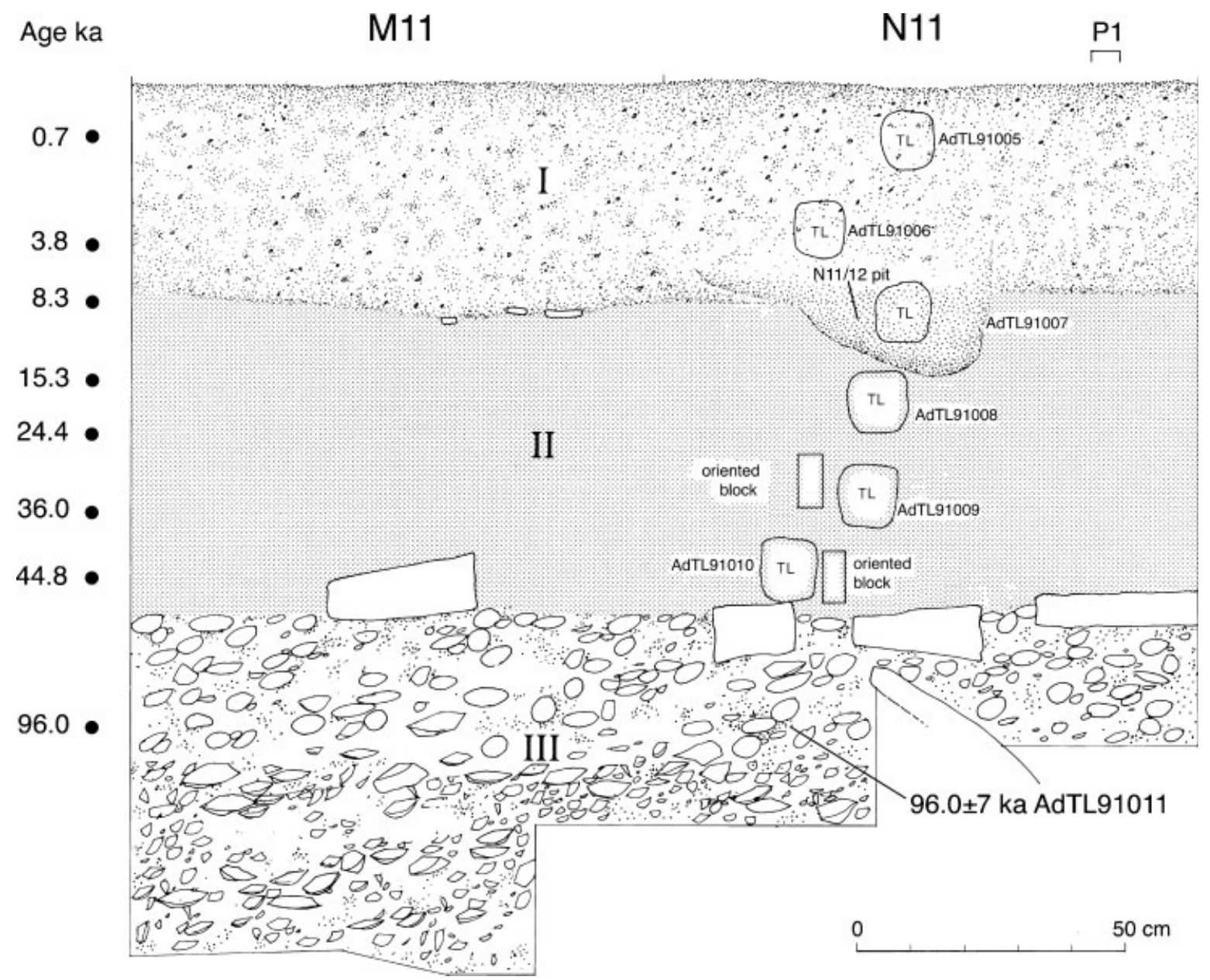

Figure 5 Stratigraphic section, east face of the Main Trench, grid squares M11 and N11, Puritjarra, showing horizontal bedding of layers I-III and position of phytolith column (P1) and TL samples. Ages (ka) are interpolated from ${ }^{14} \mathrm{C}$ (calibrated) and TL date series for site. For details of the age model see Smith et al. (1997) 


\section{The sediments}

\section{Stratigraphic units}

Archaeological excavations showed that the rock shelter sediments are $>2 \mathrm{~m}$ deep and consist of three major lithostratigraphic units: layers I to III (Fig. 5). These are subhorizontally bedded and preserve a sedimentary record spanning the last ca. $100 \mathrm{ka}$. Chronological control for the site is provided by 31 radiocarbon ages on charcoal, nine thermoluminescence $(T L)$ ages on rock shelter sediments and three accelerator mass spectrometry (AMS) ${ }^{14} \mathrm{C}$ ages on calcium oxalate skins on rock surfaces (Smith et al., 1997, 2001, 2009; Prescott et al., 2007).

\section{Layer III}

This layer forms the structural basal unit across the site. The upper part of the layer is late last interglacial in age, dated by AdTL91011 $96 \pm 7 \mathrm{ka}$ (1.2 $\mathrm{m}$ below surface). The lower part of the unit is substantially older, but AdTL89012 (270 $\pm 55 \mathrm{ka}$, $2.1 \mathrm{~m}$ below surface) may overestimate the actual age because of in situ granular disintegration of sandstone roof fall. The large block fall within layer III represents the last major event to alter the morphology of the rock shelter significantly (though some block fall continued throughout the history of the site). Since that time, there has been little retreat of the overhang. Excavations in N18 revealed a column of rocks, shed from the leading edge of the overhang, showing that this was in its present position during the deposition of layer II.

Layer III consists of boulders, large rocks and well-rounded sandstone rubble in a matrix of loose, fine, dark red sand (Munsell 10R 5/8; pH 3.5). It is $>1.20 \mathrm{~m}$ thick (but was only substantially probed in the main trench) and grades upwards from large boulders and subangular fragments in a sandy matrix to rounded sandstone cobbles and pebbles in a sandy clay matrix. The layer represents a gradual accumulation of roof fall and aeolian sand. Spaces between boulders are entirely filled with aeolian sand. No voids are present. Accretion of fine sediments (sands, silts and clays) appears to have ceased after $96 \mathrm{ka}$, and the surface of layer III forms a discrete surface of rounded cobbles and compacted clay. Spot heights for this surface show it to be $40 \mathrm{~cm}$ higher in the central and southern sectors of the shelter (reflecting the distribution of roof fall), with the northern sector forming a shallow depression. It is in this depression that layer II began to accumulate.

\section{Layer II}

Aggradation of fine sediments recommenced around $45 \mathrm{ka}$, with deposition of a distinctive Late Pleistocene unit of compact, fine red clayey sand (Munsell 5YR 5/8 grading to 2.5 YR $5 / 8 ; \mathrm{pH} 3.0)(49 \%$ sand, $32 \%$ silt and $18 \%$ clay at $75 \mathrm{~cm}$ below surface). Layer II rests unconformably on layer III, and is dated at its base by AdTL91010 (44.8 $\pm 3.6 \mathrm{ka}, 93 \mathrm{~cm}$ below surface). The upper part of the unit ranges in age from 36 to 35 ka (AdTL91009 34.6 $\pm 1.6 \mathrm{ka}$; OZA731 $32400 \pm 500{ }^{14} \mathrm{C}$ a $\mathrm{BP}, \mathrm{ANUA} 1001331,140 \pm 470{ }^{14} \mathrm{C}$ a BP) to the mid Holocene, $8.3 \mathrm{ka}\left(7500{ }^{14} \mathrm{C}\right.$ a BP).

Layer II is $0.60 \mathrm{~m}$ thick in the northern part of the shelter, but thinner $(0.25 \mathrm{~m})$ at the rear of the shelter (ST5) and in the southern sector (Z9/Z10), where it is less consolidated with a more sandy texture. Within layer II, silt and clay content increases with depth from $35 \%$ to $60 \%$ (Fig. 6). Gravel often forms discrete horizontal bands indicating short pulses of fine sedimentation or of fine rock fall, but no discrete surfaces are evident in thin-section micromorphology.

Layer II cannot be traced outside the rock shelter. Excavations in N25 (on the sand plain $7 \mathrm{~m}$ outside the shelter - see Fig. 3) cut through $2 \mathrm{~m}$ of undifferentiated modern aeolian sands (to $2.13 \mathrm{~m}$ below datum) without encountering distinctive layer II sediments. This suggests that the Late Pleistocene rock shelter deposits were perched above the local sand plain, and that the rock shelter at this time may have opened onto a low scree slope.

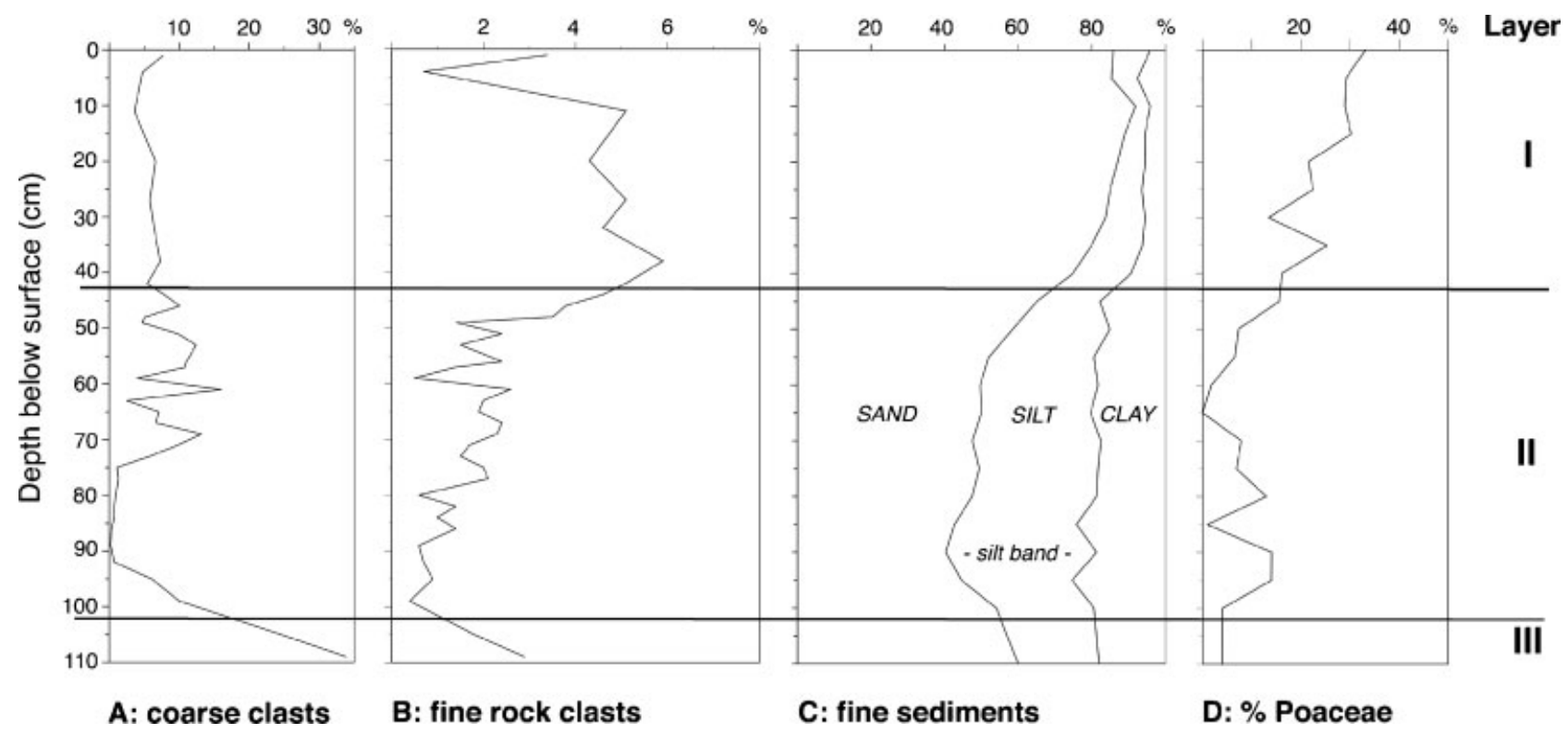

Figure 6 Global granulometry diagram, Puritjarra rock shelter. Changes in the silt/clay content of the fine sediments and in the size grade of roof-fall mark the transition from layer II to layer I. (A) Coarse rock clasts, 6-50 mm. (B) Fine rock clasts, 3-6 mm. (C) Textural data for fine sediments (sands, silts, clays). (D) Phytolith data showing changing representation of grass vs. shrubs/herbaceous vegetation (Poaceae vs. dicotyledons and (non-Poaceae) monocotyledons). Sources: (A) and (B), excavation data from N12; (C) grain-size analyses of fine sediments from N11, P1 column in Fig. 5; (D) published data on phytoliths (P1 column), from Bowdery (1998: Fig. 6.1 and Table 15.1) 
The upper part of layer II contains archaeological evidence for repeated use of the rock shelter by people, beginning around $36-35 \mathrm{ka}\left(32000{ }^{14} \mathrm{C}\right.$ a BP). At that time, the major area of level rock-free floor was in the northern part of the shelter. As layer II built up, it buried much of the rockfall and rubble in other parts of the shelter, extending the area available to people as a living surface.

\section{Layer I}

Layer I is a consolidated layer (0.40-0.42 m thick) of sand and rock spall dating to the mid to late Holocene. It extends across the entire site, grading into aeolian sediments outside the rock shelter. Deposition of this unit began $8.3 \mathrm{ka}$ and reflects a sharp shift in the character of the rock shelter sediments rather an abrupt break in sedimentation. Thin sections do not show any unconformity between layers I and II.

The matrix of layer I is made up of light-brown sand (Munsell 5YR 5.8; pH 3-4.5), sandstone rubble and numerous fine rock fragments. The layer contains lenses of rockfall, intact hearths and pits, well-distributed pieces of charcoal and finely fragmented bone. The orientation of rocks indicates subhorizontal bedding but there is little internal stratification. The modern floor slopes from south to north across the rock shelter (following the trend of the underlying layers II and III) to a topographic low on the northern edge of the drip line (Fig. 3).

\section{Post-depositional changes}

There has been no significant post-depositional alteration of layers I and II. Thin sections show little mobilisation of silt and clay within the profile, with no evidence for deposition of clay around voids and in pore spaces. In both layers, the edges of archaeological features, such as pits and hearths, can be traced. Minor bioturbation by ants occurs across the interface of $\mathrm{I} / \mathrm{II}$, as small aliquots of redder layer II sediments are visible in the basal $20-40 \mathrm{~mm}$ of layer I. The main post-depositional change to these sediments is increasing compaction with depth of layer II. Layer III, however, has been subject to a long period of subaerial weathering. The top of this layer is compacted relative to underlying sediments, with rocks aligned with the surface. Rounded sandstone cobbles or subangular pieces with rounded edges are common near this surface but decline in frequency with depth.

\section{Sedimentology}

The sediments reflect two main sources: fine aeolian sediments originating outside the shelter; and varying size grades of sandstone clasts derived from the shelter itself.

\section{Sandstone clasts}

Weathering of local sandstone has contributed significant amounts of rock clasts to the deposit, forming up to 15\% (by weight) of the deposit in layers I and II and $>50 \%$ in layer III (Fig. 6). At the finer end of the range $(0$ to $-2 \phi)$ these clasts are well patinated on at least one surface and are lamellar, subangular or elongate in shape, indicating their origin as rock spall. The coarser fraction comprises boulders and subangular cobbles of $>50 \mathrm{~mm}$. Two different weathering processes are evident:
Table 1 Grain-size statistics for Puritjarra sediments, using the inclusive graphic statistics of Folk (1980). Depths are cm below surface. Values in parentheses are for the sand fraction only

\begin{tabular}{lcccccc}
\hline Sample & Depth $(\mathrm{cm})$ & Mo $(\varnothing)$ & $M_{\mathrm{z}(\varnothing)}$ & $\sigma_{\mathrm{I}}(\varnothing)$ & $S_{\mathrm{k}_{\mathrm{I}}}$ & $K_{\mathrm{G}}$ \\
\hline Layer I & 0 & $2.5-2.75$ & $3.0(2.48)$ & $(0.76)$ & $(-0.23)$ & $(1.21)$ \\
Layer II & 80 & $2.5-2.75$ & $5.5(2.78)$ & $(0.69)$ & $(-0.51)$ & $(1.31)$ \\
Layer II & 95 & $2.75-3.0$ & $6.1(2.90)$ & $(0.39)$ & $(+0.08)$ & $(1.23)$ \\
Layer III & 173 & $2.75-3.0$ & $4.2(2.70)$ & $(0.69)$ & $(-0.18)$ & $(1.46)$
\end{tabular}

- Large boulders and cobbles $(>50 \mathrm{~mm})$ are related to structural failure or unloading of the shelter roof, particularly in the central part of the shelter and near the rear wall, where a rock shelf has collapsed.

- Rock clasts in the pebble and granule size grades are concentrated in a lateral swathe across the shelter, beneath a prominent step in the roof of the shelter (Fig. 4) and reflect physicochemical spalling of the shelter roof.

Figure 6 shows that the size grade of rock clasts in the rock shelter sediments changed from coarse clasts $(6-50 \mathrm{~mm})$ in layer II to predominantly fine rock clasts $(3-6 \mathrm{~mm})$ in layer I. The latter indicates a more aggressive weathering regime within the rock shelter, initiated around 13-12 ka and well established by $8.3 \mathrm{ka}$.

\section{Sand fraction}

The proximate sources of the fine sediments (sands, silts and clays) are sand ridges and inter-dune corridors upwind of the rock shelter. Grain-size analysis shows that the fine sediments have a major peak in the fine sand range $(2.5-2.75 \phi)$ and secondary modes representing coarse sand (0.5-0.75 $\phi)$ and fine silt and clay (7-8 $\phi)$ (Table 1 and Fig. 7). The latter reflects laboratory disaggregation of sand-sized silt/clay pellets in these sediments.

The fine sand fraction is predominantly aeolian in origin, consisting of well-rounded grains of mature $150 \mu \mathrm{m}$ quartz with ferruginised coatings, matching dune and sand plain sediments in general appearance and grain-size characteristics (Folk,

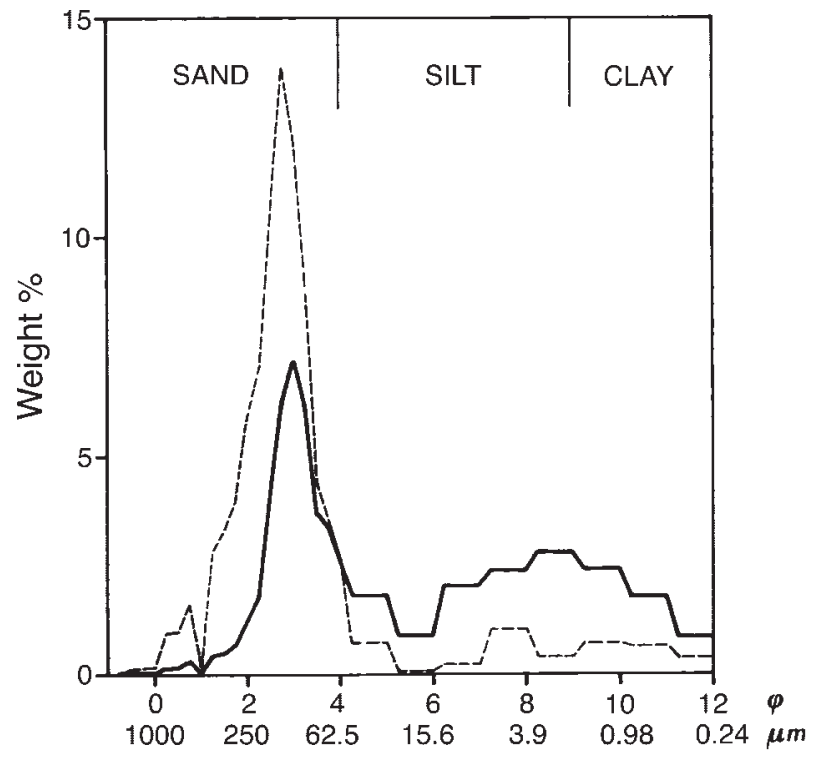

Figure 7 Grain-size distribution of fine sediments at Puritjarra. Bold line: base of layer II (95 cm below surface); dotted line: top of layer I (surface) 
1971). Local dune sands in the Puritjarra area have a similar size distribution to the shelter sediments, but lack silt/clay aggregates. Local Mereenie sandstone has not significantly contributed to the sand fraction in the rock shelter sediments. This sandstone is coarser than the shelter sediments $(2 \phi$ compared to $2.5-2.75 \phi)$, contains no silt or clay, and its constituent quartz grains lack the ferruginised coatings of the rock shelter sediments.

Grain-size analysis shows the sand mean $\left(M_{z}\right)$ became coarser over time, from $2.90 \phi$ at the base of layer II to $2.48 \phi$ at the top of layer I, with corresponding changes in sorting of the sand fraction $\left(\sigma_{1}\right)$ (Table 1). Given that the crests of linear dunes in Central Australia have coarser material than the flanks (Folk, 1971), these changes reflect greater input of sand from active crests during the accumulation of layer I. Luminescence dating of sandridges near the rock shelter confirms that local dune crests remained active into the late Holocene (e.g. AdTL91003, $1.58 \pm 0.11 \mathrm{ka})$.

\section{Silt and clay fraction}

There is little free silt or clay in these sediments. Thin sections show that at Puritjarra this material is in one of two forms (Fig. 8):

- sand-sized clay aggregates, typically about 2.75-3.25 $\phi$ $(100-150 \mu \mathrm{m})$ in size (maximum size range $1-4.25 \phi$ or 50-500 $\mu \mathrm{m})$, often with enclosed quartz grains;

- clay or silt skins coating quartz grains (cutans). These are typically about 20-50 $\mu \mathrm{m}$ thick but range from 5 to $150 \mu \mathrm{m}$. These skins often show prominent concentric layering. Some grains have only a remnant of the clay skin remaining in concavities on the surface of the grain (especially in layer I).

Clay aggregates and grain cutans form in clay-rich soils subject to periodic wetting and drying (Brewer, 1964; FitzPatrick, 1984; Rust and Nanson, 1989), though salts are normally required for formation of aggregates (Bowler, 1973). These cannot have formed in situ at Puritjarra because the rock shelter sediments lack sufficient clay to produce the swelling and cracking involved in the formation of clay aggregates. The rounding of the clay aggregates in the Puritjarra sediments - and the preservation of comparatively large aggregates $(500 \mu \mathrm{m})$ indicates aeolian transport from a nearby palaeosol. As local dune sediments have less than $4 \%$ silt/clay, the most likely source is deflation of clay-rich red earths that occur in interdune corridors upwind of the shelter.

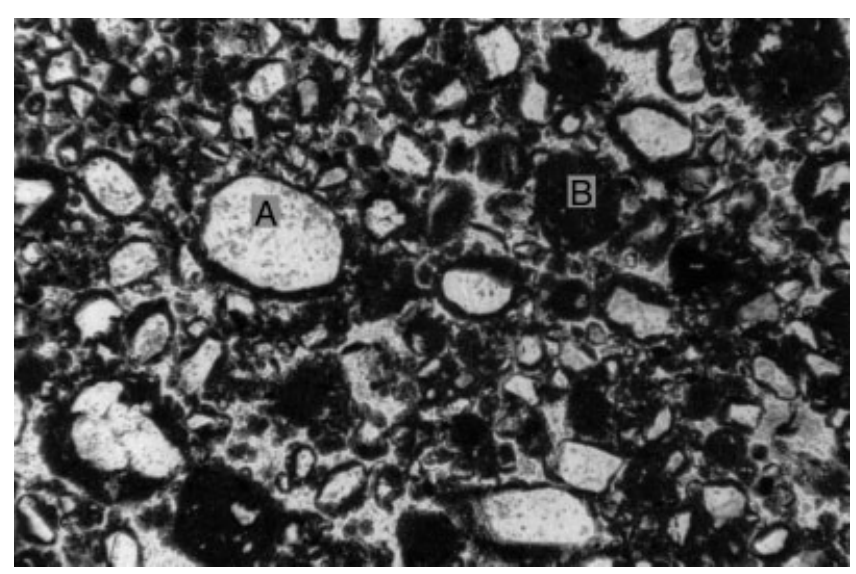

Figure 8 Thin section of layer II sediments from Puritjarra rock shelter (75 cm below surface, west face of N13), showing (A) grain cutans and (B) clay aggregates. Plane-polarised light. Width of image $=2.0 \mathrm{~mm}$
This is also reflected in spatial variation in the texture of the rock shelter sediments, which mirrors the dune and swale topography outside the shelter: the northern sector of the rock shelter opens upwind into an inter-dune corridor and receives clay-rich material from the swale and flanks of the local dunes; the southern sector receives predominantly fine sand from the crest of the sand mound in front of the shelter. The high acidity of the Puritjarra sediments (field $\mathrm{pH} 3.0$ ) is due to the presence of soluble sulphate $\left(0.18 \% \mathrm{SO}_{4}\right.$ at the base of layer II), reflecting seeding of local palaeosols with gypsum deflated from playas in the Lake Amadeus chain (100 km south of Puritjarra). This longdistance transport of salts from playas may have enabled clay pellet formation in inter-dune swales, as Fitzsimmons et al. (2007b) also hypothesise for the Lake Frome region.

Although the silt and clay mainly occur as aggregates, one exception to this pattern is a band of loess at $90 \mathrm{~cm}(45-40 \mathrm{ka})$ (Fig. 6). Grain-size analyses show a localised peak in medium silt $(5-6 \phi)$ that can be traced across the northern sector of the site, but which is not evident in either thin sections or stratigraphy. The absence of laminae in thin sections argues against water ponding as the proximate source of this silt. Aeolian dust carried in local suspension seems more likely.

Grain-size analyses show that the amount of silt and clay decreased over time, from $50 \%$ in layer II to $10-20 \%$ in layer I (Figs 6 and 7). The thin sections also show that clay aggregates and grain cutans are rare in layer I and tend to be reworked and restricted to concavities on the surfaces of grains. This confirms trends evident in the sand fraction: layer II registers active deflation of palaeosols in the region, as well as dunes with mobile flanks and crests. Layer I reflects a different sedimentary regime, where inter-dune areas have been revegetated and only the crests of dunes are still mobile.

\section{Palaeoecology}

The main source of palaeoecological data at Puritjarra is the phytolith record (Bowdery, 1995, 1998), which provides a long continuous record of local grassland and herbaceous vegetation spanning the last $45 \mathrm{ka}$, with isolated samples from last interglacial (layer III) levels. This is supplemented by evidence of tree and shrub taxa from assemblages of charcoals (Smith et al., 1995) in several time periods: late Holocene $(<0.7 \mathrm{ka})$, early Holocene/terminal Pleistocene (15.3-8.3 ka), Last Glacial Maximum (LGM) (24-20 ka) and pre-LGM (36-24ka). Pollen and animal bone provide more limited records, but add to the late Holocene picture.

\section{Phytoliths}

The long phytolith record has not received the attention it merits, largely because Bowdery did not pursue its interpretation in any detail. However, multivariate analysis of phytolith spectra (using the shape class counts from Bowdery, 1998: Table 15.1) resolves questions about the source of the phytoliths and provides a systematic comparison of phytolith assemblages from different levels.

\section{Sources of phytoliths}

Although Bowdery was not clear on the likely source of phytoliths at Puritjarra, the assemblage predominantly represents the regional (extra-local) vegetation. Plants growing 


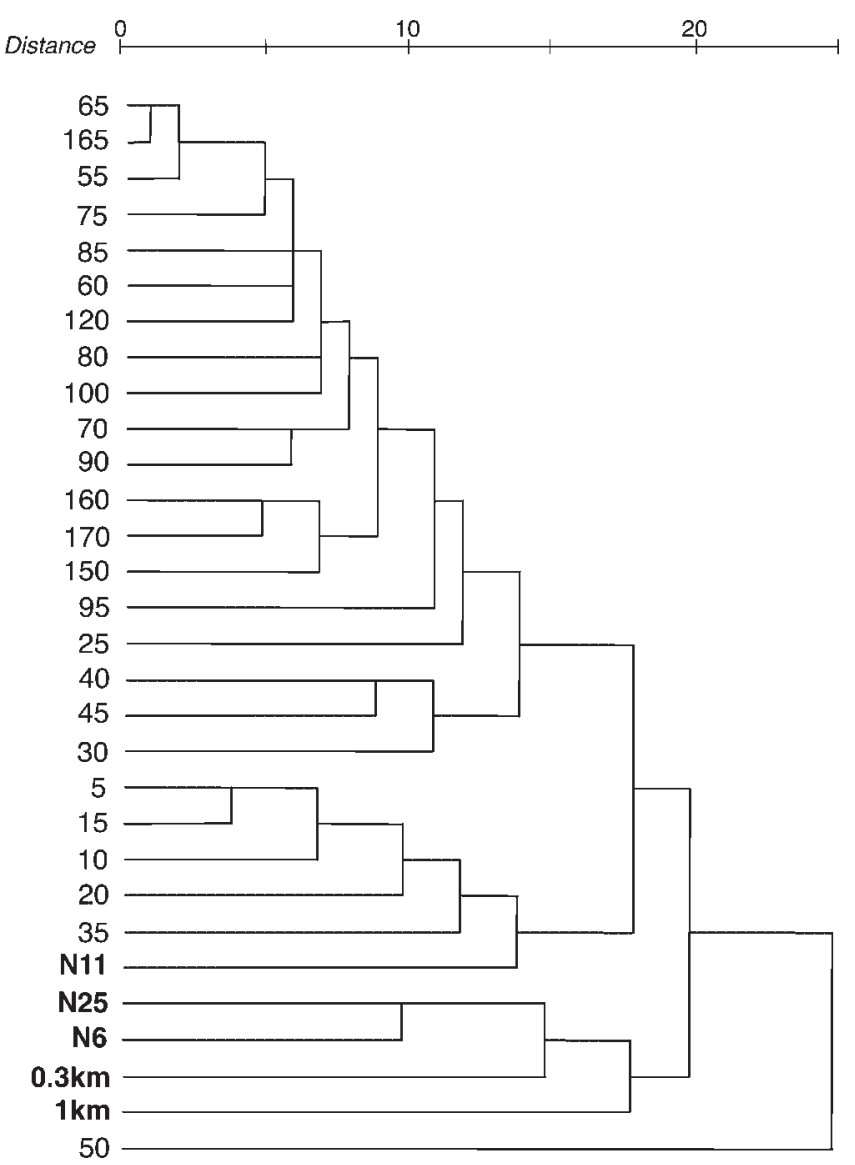

Figure 9 Cluster analysis of Puritjarra phytolith assemblages (N11, P1 column, layers I-III). Numbers are sample depths below surface. Surface samples are shown in bold. These show that modern phytolith spectra within the rock shelter (N6) group with samples taken along a transect outside the shelter (at $\mathrm{N} 25 ; 0.3 \mathrm{~km}$ and $1 \mathrm{~km}$ out from the shelter). Maximum divergence from modern phytolith spectra is shown by sample 65 (top of diagram) representing the LGM. Cluster analysis was carried out with SPSS, using average linkage between groups, with variables (counts for each shape class) standardised to Z-scores

directly on the site do not appear to have swamped these phytolith spectra. Potential sources of phytoliths include: a local (decay in situ) component; an extra-local (regional) component; long-distance transport $(>100 \mathrm{~km})$; and material reworked from older deposits. The relative contribution of these factors can be gauged by comparing phytolith spectra from the surface of the deposit with the modern vegetation. Comparison of surface samples from two locations in the rock shelter (N6 and N11) and three locations outside on the sand plain $(7 \mathrm{~m}$, $342 \mathrm{~m}$ and $1 \mathrm{~km}$ away) showed these all have similar phytolith spectra, which group in a cluster analysis (Fig. 9). Plant species that grow within the shelter, mainly Nicotiana sp. and Abutilon sp., are not well represented in modern phytolith spectra and it is possible that neither plants are prolific producers of phytoliths. The low rate of sediment accumulation and wind eddies within the rock shelter also indicate that local phytolith fluxes are likely to be redistributed and averaged before burial.

An extra-local source is consistent with the size range of phytoliths in the Puritjarra sediments: most are between 50 and $150 \mu \mathrm{m}$, material readily carried by aeolian processes over short to medium distances. Strong seasonal winds, open ground and periodic wildfires all present opportunities for entrainment of this material. The presence of sponge spicules (Porifera: Spongillidae) throughout the profile suggests some aeolian transport from athalassic saline environments like Lake Amadeus (Racek, 1969) 60-100 km away. But significant long-distance (extra-regional) transport is unlikely because material $<50 \mu \mathrm{m}$ generally remains in suspension until washed out by rain, and the morphology of the rock shelter precludes deposition from this source. Local Ordovician/Devonian sandstones do not appear to contain phytoliths or sponge spicules.

\section{Temporal trends}

Local grasslands appear to have been well established during the last interglacial (MIS 5) as there is a marked peak in Poaceae $>96$ ka (layer III, $160 \mathrm{~cm}$ ) with grass values $(28.4 \%$ ) approaching modern levels (29-33\%).

The Late Pleistocene vegetation (45-15 ka) was dominated by trees and shrubs and other herbaceous plants. This was a period of major instability in the herbaceous flora with overall low representation of grasses. The impact of increasing aridity is clearly shown in the decline in Poaceae values after $45 \mathrm{ka}$. Figure 6 shows two periods of pronounced aridity: one at $24 \mathrm{ka}$ (ANUA10010 $20110 \pm 250{ }^{14} \mathrm{C}$ a BP), probably representing the LGM and an earlier one around $40-36 \mathrm{ka}(85 \mathrm{~cm}$ below surface). Each of these involved a sharp decline in Poaceae (Fig. 6), as well as significant perturbations in the herbaceous flora on the shoulders of an arid spike (Fig. 10). The LGM saw the elimination of most grasses from the regional vegetation. These levels have extraordinarily low phytolith counts, comparatively small phytoliths, and the lowest diversity of phytolith shapes - all indicative of a period of marked aridity.

Grass values steadily increased after $15 \mathrm{ka}$ to a peak in the early Holocene before sharply declining at $3.8 \mathrm{ka}$, and recovering again to reach modern levels by $1.4-1.5 \mathrm{ka}$ (Fig. 6). Correspondence analysis of phytolith spectra (Fig. 10) shows that changes in relative abundance of Poaceae account for most of the variability during the last $5000 \mathrm{a}$, with a progression towards more grass over time. These changes must reflect Holocene expansion of spinifex (hummock grassland) communities, but these cannot be traced directly as Triodia phytoliths are not distinctive. Chloridoid (Eragrostis and Tragus), Eu-Panicoid (Setaria, Digitaria, Yakirra) and some new Danthonoid grasses became more prominent after 2-1.5 ka, joining a grass flora already containing taxa such as Eriachne and Aristida (Bowdery, 1998). All of these grasses (except Tragus) are common in spinifex communities (Lazarides, 1970: 10) and mark the establishment of the modern vegetation formations near the rock shelter.

Grass species in Central Australia are predominantly summer rainfall species (Lazarides, 1970: 7). Therefore, as a record of the contraction and expansion of local grasslands, the Puritjarra phytolith spectra also provide a proxy for summer rainfall in Central Australia. This was high during the last interglacial, declined from $45 \mathrm{ka}$ to minima at $40-36 \mathrm{ka}$ and $24 \mathrm{ka}$, and then recovered strongly after $15 \mathrm{ka}$. Summer rainfall appears to have become more effective during the early Holocene (10-6 ka), but the period from $1.5 \mathrm{ka}$ represents the highest values since the last interglacial.

\section{Charcoals}

Although the phytolith record shows increasing representation of grassland in the Holocene, and a corresponding decline in shrubland and herbaceous vegetation, the charcoals show that there were also changes in the composition of woody taxa into the Holocene. The archaeological charcoals mostly represent fuel selected by people using the rock shelter. However, Smith et al. (1995) show that the relationship between the late 


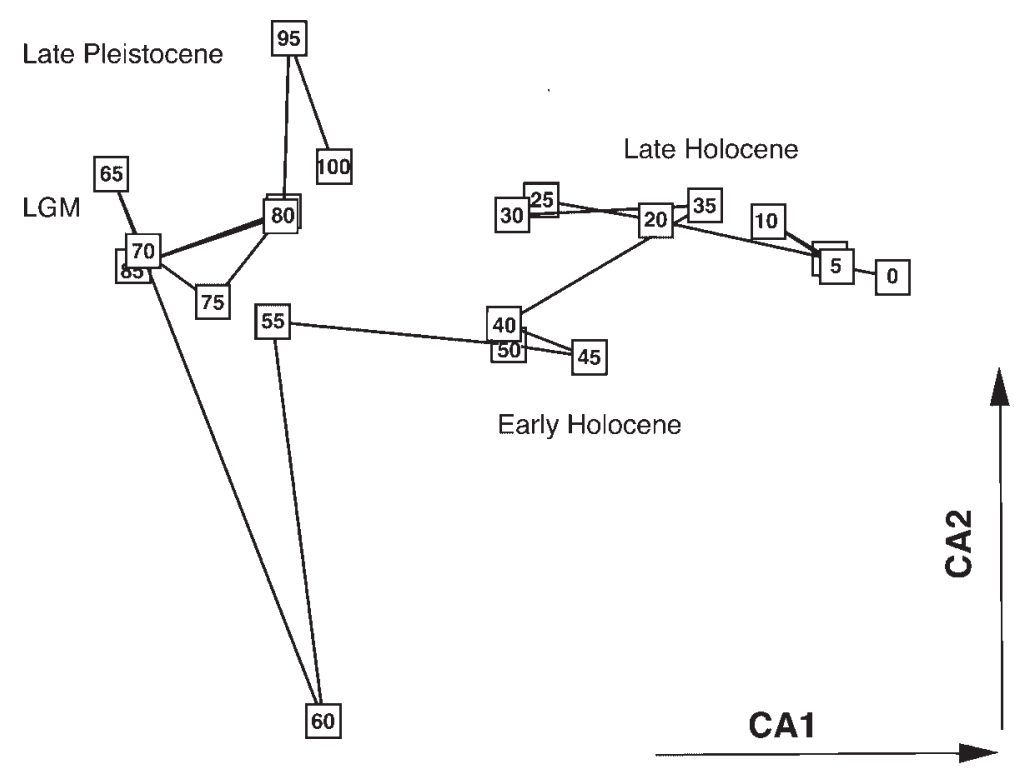

Figure 10 Correspondence analysis of phytolith assemblages (N11, P1 column). Samples are numbered according to depth (cm) below surface and plotted against the first two components. Component CA1 (variability 43.3\%) represents the relative abundance of Poaceae in these assemblages, and shows the postglacial expansion of local grasslands (increasing towards the right) that can be seen in Fig. 6(D). Component CA2 (variability 14.6\%) represents variability in shrub and herbaceous taxa, and shows marked instability during the Late Pleistocene. The LGM is represented by sample 65 at the left of the diagram. Multivariate analysis was carried out with MV-ARCH (Wright, 1992). Data are phytolith counts for layers I and II from Bowdery (1998: Table 15.1) excluding amorphous phytoliths (shape class x), and normalised to $100 \%$ for each sample

Holocene charcoals and the modern woody vegetation of the area is predictable and relatively systematic, as certain species provide better fuel wood - and people preferentially used these if available.

Like the phytoliths, the charcoals show that the Late Pleistocene vegetation was structurally different from that of the Holocene, comprising more open shrubland with fewer trees. Major identified taxa (36-24 ka) include sandhill shrubs, such as Grevillea juncifolia, and trees such as Corymbia opaca (bloodwood), Callitris glaucophylla and Allocasuarina decaisneana (desert oak). Some acacias were present but mulga (Acacia aneura) woodland was not a significant element in the shelter's catchment prior to $15 \mathrm{ka}$. This pattern continued into the LGM, where the persistence of sandplain trees (C. opaca) and species characteristic of rocky gorges and escarpments Eucalyptus papuana (ghost gum) and C. glaucophylla-indicate that despite increasing aridity the region was not a treeless steppe.

From $15 \mathrm{ka}$, acacias are more strongly represented both quantitatively and in terms of the number of species present (Table 2; Fisher's exact test, $P=0.0297 ;<15 \mathrm{ka}$ : Acacia 35, non-acacia 48; >15 ka: Acacia 13, non-acacia 36). A. aneura becomes a major component of charcoal assemblages only after $15 \mathrm{ka}$ (Fisher's exact test: $P=0.0028 ;<15 \mathrm{ka}$ : $A$. aneura 19 , other charcoal 81 ; $>15 \mathrm{ka}$ : A. aneura 0 , other charcoal 33). Eucalyptus camaldulensis, found along watercourses in the region today, also appears after $15 \mathrm{ka}$. Taken together with the

Table 2 Changes in the relative importance of Acacia charcoals in the Puritjarra assemblage. Data are percentage frequency of pieces (excluding unidentifiable pieces). Figures in parentheses are raw counts

\begin{tabular}{lccc}
\hline Time period & $<1 \mathrm{ka}$ & $8-15 \mathrm{ka}$ & $24-36 \mathrm{ka}$ \\
\hline Acacia & $42(16)$ & $42(19)$ & $27(13)$ \\
Eucalyptus/Corymbia & $34(13)$ & $22(10)$ & $39(19)$ \\
Callitris & $9(3)$ & $20(9)$ & $14(7)$ \\
Allocasuarina & $5(2)$ & $2(1)$ & $6(3)$ \\
\hline
\end{tabular}

Copyright (c) 2009 John Wiley \& Sons, Ltd. phytolith evidence, these results suggest that both spinifex grassland and mulga woodland communities expanded after the LGM, following re-establishment of the summer monsoon circulation around 15-14 ka (Singh and Luly, 1991; Wyrwoll and Miller, 2001).

\section{Pollen}

Previous work has shown that some arid zone rock shelter deposits preserve pollen (Martin, 1973, 1977). At Puritjarra, pollen is only preserved within the upper part of layer I. Table 3 shows results for a sample from $\mathrm{N} 10(12 \mathrm{~cm}$ below surface $)$ dating to $0.7 \mathrm{ka}$. Poaceae and Eucalyptus are the most common elements, with the local rock vegetation represented by Sida pollen. All of the taxa identified can be found around the rock shelter today. The Rubiceae pollen probably represents Canthium latifolium (native currant), a small shrub that presently grows along the dripline of the shelter.

Table 3 Pollen identified at Puritjarra, from the upper part of layer I ( $12 \mathrm{~cm}$ below surface). Relative abundance: common or very common $(++++)$, present $(++)$, rare or very rare $(+)$

Pollen taxa Relative abundance

Myrtaceae (cf. Eucalyptus)

Poaceae

Malvaceae (cf. Sida)

Gyrostemon or Condocarpus

Eucalyptus (E. socialis)

Fern spore

Rubiaceae

Casuarina

Chenopodiaceae

Asteraceae

++++
++++
++
++
++
++
++
++
+
+


Table 4 Fragmentation of bone at Puritjarra. Following $\mathrm{O}^{\prime}$ Connor et al. (1998), the index of fragmentation is total bone weight/total number of fragments. For analytical units see Smith (2006)

\begin{tabular}{lcccc}
\hline Analytical unit & $1 \mathrm{a}$ & $1 \mathrm{~b}$ & $1 \mathrm{c}$ & All bone \\
\hline Time period ka & $<0.7$ & $0.7-3.8$ & $3.8-8.3$ & \\
Total no. fragments & 1799 & 1012 & 75 & 3452 \\
Total bone wt $(\mathrm{g})$ & 62.6 & 50.9 & 2.0 & 143.4 \\
Index of fragmentation & 0.035 & 0.050 & 0.027 & 0.042 \\
\hline
\end{tabular}

\section{Faunal remains}

Bone was recovered from the $6 \mathrm{~mm}$ sieve fraction throughout layer I (no bone is preserved in layer II). Like most archaeological faunal material from the arid zone (Veth, 2005: 104), the Puritjarra bone is extremely fragmented (Table 4) due to a range of taphonomic and depositional factors, including the human practice of pulverising bone for consumption. Nevertheless, the assemblage (Table 5) is characteristic of the range of habitats surrounding Puritjarra, with species representing spinifex and sandhill country (Pseudomys hermannsburgensis, Isoodon auratus, Lagorchestes hirsutus), rocky hills and escarpments (Petrogale lateralis, Macropus robustus), mulga woodlands (Macropus rufus) and clay loams in inter-dune areas (Bettongia lesueur). Although the assemblage is small, the greatest species diversity is in the upper part of layer I $(<0.7 \mathrm{ka})$, consistent with the vegetation evidence for higher summer rainfall and well-established spinifex grasslands at this time.

Table 5 Faunal remains at Puritjarra. Data are number of identified fragments per taxon (NISP) for the $6 \mathrm{~mm}$ sieve fraction

\begin{tabular}{|c|c|c|c|}
\hline \multirow[t]{2}{*}{ Taxa } & \multicolumn{2}{|c|}{ Analytical unit } & Total no. \\
\hline & $\begin{array}{c}1 \mathrm{a} \\
<0.7 \mathrm{ka}\end{array}$ & $\begin{array}{c}1 \mathrm{~b}-1 \mathrm{c} \\
0.7-8.3 \mathrm{ka}\end{array}$ & \\
\hline
\end{tabular}

\section{Mammals}

Muridae

Pseudomys hermannsburgensis

Dasyuridae $^{a}$

Peramelidae $^{b}$

Bettongia sp.

Bettongia lesueur

Lagorchestes hirsutus

Petrogale lateralis

Macropus sp.

Macropus rufus

Macropus robustus

Reptiles

Agamidae

Varanidae

Agamidae/Scincidae

Scincidae

Unidentified snake

Other unidentified reptile ${ }^{c}$

Unidentified fragments

$\begin{array}{rrr}6 & & 6 \\ 3 & & 3 \\ 1 & & 1 \\ 3 & 8 & 7 \\ 2 & 1 & 8 \\ & 8 & 1 \\ 3 & & 3 \\ 1 & & 1 \\ 39 & 26 & 65 \\ 3 & & 3 \\ 7 & 4 & 11 \\ & & 2 \\ 2 & & 2 \\ 2 & & 6 \\ 6 & & 2 \\ 2 & & 18 \\ 1 & & 3309 \\ 15^{\mathrm{d}} & 4 & \\ 1703 & 1609 & \end{array}$

a Identification as dasyurid not certain but size indicates $D$. geoffroii rather than one of the small dasyurids.

${ }^{\mathrm{b}}$ Possibly Isoodon auratus, the common bandicoot in this area.

${ }^{\mathrm{c}}$ Mainly reptile vertebrae.

${ }^{\mathrm{d}}$ Includes one reptile scale.

\section{Discussion: late Quaternary landscapes in Central Australia}

Puritjarra rock shelter occupies a strategic location with regard to other Quaternary research in Central Australia (Fig. 1). The Amadeus basin to the south forms the major groundwater discharge zone in Central Australia, where saline and hypersaline groundwater discharge in a chain of playas extending more than $600 \mathrm{~km}$. Chen et al. $(1990,1991,1993)$ outline the Quaternary history of the largest of these playas: Lake Amadeus (60-100 km south of Puritjarra). Jacobson et al. (1989) reconstructed the history of the groundwater in the basin and Megirian et al. (2002) describe an early Holocene fauna from Mygoora Lake, one of the smaller playas. The main Central Australian Range complex (including the MacDonnell and George Gill Ranges) begins $60 \mathrm{~km}$ to the east of Puritjarra, and includes the headwaters of the major drainages in Central Australia. The fluvial histories of these ephemeral rivers have been worked out in various studies: Finke River (Pickup et al., 1988; Nanson et al., 1995; Hollands et al., 2006); Todd River and its tributaries Ross River and Giles Creek (Bourke, 1998; Patton et al., 1993); Sandover River (Tooth, 1997). Within the ranges, Leporillus rat middens provide localised records of vegetation over the last 2000-3000 a (Nelson et al., 1990; Berry, 1991; Webeck and Pearson, 2005). English et al. (2001) have reconstructed the fluvial and lacustrine history of Lake Lewis (175 km north-east of Puritjarra), an ephemeral lake on the northern side of the MacDonnell Ranges, strongly influenced by stream flows from the mountainous catchment (900 $\mathrm{m}$ above local piedmont fans) surrounding this basin. A chronology for linear dune activity on the western and eastern margins of the Simpson Desert dune field is provided by Hollands et al. (2006), Nanson et al. (1995), and Twidale et al. (2001), with Jacobson (1996) and Chen et al. (1991) providing dates on linear dunes in the Amadeus basin itself.

Against this context, Puritjarra provides a local record of a landscape progressively responding to increasing aridity from $45 \mathrm{ka}$, with deflation of clay-rich palaeosols (from $45 \mathrm{ka}$ ), entrainment of aeolian dust (45-40 ka) and sharp declines in grassland and other vegetation cover (at 40-36 ka and $24 \mathrm{ka}$ ) leading into the LGM. The area recovered steadily from $15 \mathrm{ka}$ with expansion of both acacia woodland and local grasslands.

\section{Last Interglacial (MIS 5)}

The evidence from Puritjarra indicates an interglacial landscape with open grass-rich vegetation and at least seasonally active dunes, analogous to conditions around the rock shelter today. At Lake Amadeus, to the south, the deposition of shoreline gypsum $>82$ ka shows that although the regional water table was high this included hypersaline brines subject to seasonal drought and deflation (Chen et al., 1990, 1991). An offshore core near Exmouth (Fr10/95 GC17) records open grassrich Eucalypt woodlands in the northern part of the arid zone, between 100 and 70 ka (van der Kaars and De Deckker, 2002). This evidence for more effective summer rainfall combined with strong seasonality is consistent with the picture of enhanced fluvial and lacustrine conditions in the Lake Eyre basin during MIS 5 (Magee et al., 1995; Maroulis et al., 2007). However, none of the large playas in western Central Australia are close enough to the hydrological threshold (Bowler, 1981) to have switched to lacustrine conditions, except for Lake Lewis (which was saline at this time) (English et al., 2001). 
Stage 3 (60-24 ka)

The unconformity between layers II and III at Puritjarra (90$45 \mathrm{ka}$ ) coincides with another phase of higher regional water tables, discharge of saline groundwater, and deflation of gypsum at Lake Amadeus at 59-44 ka (Chen et al., 1990, 1991). The weathering of layer III suggests a period of subaerial exposure of this surface with little sedimentation in the rock shelter. The environmental correlates of this are unclear but the Lake Amadeus record suggests an arid environment, with strong seasonality, involving summer drought and winter rainfall.

In the Lake Eyre basin, there is evidence that the summer monsoon weakened after $45 \mathrm{ka}$ (Johnson et al., 1999; Maroulis et al., 2007). Landscapes in the Amadeus basin also registered the impact of increasing aridity at this time. Regional water tables at Lake Amadeus were lower after $44 \mathrm{ka}$ and discharge of hypersaline brines ceased. Deflation of palaeosols in interdune corridors upwind of Puritjarra began at $45 \mathrm{ka}$, and is marked by the deposition of windblown clay aggregates in the rock shelter. This period also saw deposition of clay pellets in dune sediments in the Lake Frome region (Fitzsimmons et al., 2007b).

In western Central Australia, the Late Pleistocene vegetation (45-24 ka) was predominantly open shrubland or herbland, with isolated trees and relatively low grass values. The Fr10/95 GC17 core shows similar changes after $46 \mathrm{ka}$, with a shift to a drier regime and more open vegetation dominated by Eucalyptus and Gyrostemon shrublands and chenopods (van der Kaars and De Deckker, 2002). This may have involved a northward shift in the summer rainfall boundary and a corresponding change to a winter rainfall regime with lower overall precipitation (Hesse et al., 2004; van der Kaars and De Deckker, 2002). If so, this would also account for the structural differences between the Late Pleistocene and Holocene vegetation in Central Australia: the Late Pleistocene vegetation of the Amadeus Basin may have its closest modern analogue in vegetation formations in the southern (winter rainfall) part of the arid zone, though there is no evidence to indicate whether or not chenopods were a significant component of this vegetation.

At Puritjarra, the sharp decline in Poaceae at 40-36 ka reflects an arid event almost as marked as the LGM. This was followed by the first substantial human use of the rock shelter (36-35 ka), suggesting that increasing aridity may have triggered greater use of focal sites near waterholes (such as Puritjarra). A corresponding drop in global temperature at $36 \mathrm{ka}$ is shown in the EPICA Dronning Maud Land ${ }^{18} \mathrm{O}$ record (EPICA Community Members, 2006). Petherick et al. (2008) also identify a comparable pre-LGM peak in aridity (in this case at $30.8 \mathrm{ka}$ ) from records of aeolian dust in eastern Australia. Both records indicate episodes of accentuated millennial-scale variability in climate in the period $45-24 \mathrm{ka}$.

Reduced vegetation cover had several consequences for Central Australian landscapes. Hydrological systems became more efficient as runoff increased. Late Pleistocene palaeochannels of the Sandover River were larger, reflecting a regime of higher discharges prior to $15 \mathrm{ka}$ despite increasing aridity (Tooth, 1997). Without protective vegetation, linear dunes in the Amadeus Basin (Jacobson, 1996) and Simpson Desert (Nanson et al., 1992; Hollands et al., 2006) were remobilised between 30 and $40 \mathrm{ka}$, matching a pronounced phase of dune activity in the Strzelecki Desert further south (Fitzsimmons et al., 2007a).

One of the key questions that can be asked of a long palaeoenvironmental record like that from Puritjarra concerns the nature of Late Pleistocene environments in Central Australia prior to $35 \mathrm{ka}$. Archaeologists and other researchers have suggested that the first human movements into the interior of the continent may have taken place under conditions where water and plant and animal foods were more abundant than today (Thorley, 1998; Hiscock and Wallis, 2005; Miller et al., 2005). In contrast, palaeoecological data from Puritjarra show that people moved into an arid landscape that was structurally different from modern spinifex and sandhill habitats, but by 45-40 ka was already registering the impact of intensified aridity.

\section{LGM (24-18 ka)}

The period of maximum aridity in the Puritjarra record is at $24 \mathrm{ka}$ (ANUA10010 20,110 $\pm 250{ }^{14} \mathrm{C}$ a BP) on the shoulder of the global LGM $(21 \pm 3 \mathrm{ka})$. This suggests that vegetation in the centre of the continent may have responded more rapidly to the global changes than landforms in northern and southern Australia, where aeolian input to the Gulf of Carpentaria peaked 22-21 ka (De Deckker, 2001) and LGM moraines in the Snowy Mountains and Tasmania date 20-17 ka (Barrows et al., 2002). It is difficult to test this against other vegetation records at present because the Fr10/95 GC17 core does not show a strong peak for the LGM, with the driest period only loosely constrained between 35 and $20 \mathrm{ka}$ (van der Kaars and De Deckker, 2002).

In the Amadeus Basin, the LGM was characterised by isolated trees and sandhill shrubs, with little or no grass cover. Even spinifex (Triodia) grassland - such a ubiquitous element of the modern vegetation - was absent at this time. As Triodia is a C4 grass (McWilliam and Mison, 1974), the stable isotope evidence for an absence of $\mathrm{C} 4$ grasses in the interior during the LGM (Johnson et al., 1999) corroborates the Puritjarra record. Elsewhere in the basin, the water table at Lake Amadeus dropped sufficiently for the discharge of groundwater to cease and for a sand sheet to develop over the former playa surface. There is also widespread evidence for regionally active dunefields in Central Australia in and around the LGM, with most aeolian activity dated between 30 and $10 \mathrm{ka}$ (Chen et al., 1991, 1995; Nanson et al., 1992, 1995; Jacobson, 1996; Hollands et al., 2006).

Despite the evidence for intensified aridity, many Central Australian streams also show evidence for short but highmagnitude flows in and around the LGM, reflecting the type of interdecadel variability and extreme rainfall events that characterise arid rivers in the region today. Channels feeding Lake Lewis show major flood flows at 19-18 and $14.8 \mathrm{ka}$ (English et al., 2001) and palaeoflood deposits on Giles Creek (a tributary of Todd River) record a major flood event at $26.8 \mathrm{ka}$ (Bourke, 1998). East of Lake Eyre, Coopers Creek also shows evidence of strong but infrequent flows during the LGM (Nanson et al., 2008).

\section{Holocene transition (15-8 ka)}

Local vegetation recovered rapidly after $15 \mathrm{ka}$, registering the effects of stronger summer rainfall in the interior of the continent (Singh and Luly, 1991; Wyrwoll and Miller, 2001) with probable expansion of both spinifex grasslands and acacia woodlands. Groundwater discharge in the Amadeus Basin appears to have been re-established by about $10 \mathrm{ka}$, with evidence for shallow brines at Lake Amadeus (Chen et al., 1993). By the early Holocene, the regional vegetation may have been a mosaic of mulga (Acacia aneura) woodland and spinifex (Triodia) hummock grassland. This is supported by an early Holocene $(<12.1-9.3 \mathrm{ka})$ fauna from Mygoora Lake in the Amadeus Basin containing a diverse range of species adapted to 
xeric shrublands and grasslands, including Lasiorhinus and Sarcophilus (both locally extinct today) (Megirian et al., 2002). The effects of this transition are also apparent within Puritjarra rock shelter, where a shift to finer clasts in the deposit (13$12 \mathrm{ka}$ ) reflects more aggressive weathering of the shelter roof.

\section{Mid Holocene (8-4 ka)}

These conditions continued into the mid Holocene, with increasing evidence for fluvial activity in Central Australia and more productive plant communities near Puritjarra. By 8.3 ka revegetation of the catchment around Puritjarra had choked off sediment supply to the rock shelter and the character of the sediments changed abruptly. A similar effect is also evident at Kings Canyon ( $60 \mathrm{~km}$ south-east of Puritjarra), where runoff into the joint lines and fissures that feed the Palaeozoic sandstone aquifers on the rim of the Amadeus Basin ceased around $8.1 \mathrm{ka}$ as the recharge zone revegetated (Jacobson et al., 1989). During this period there was increased fluvial activity along the Finke River between 8.7 and $4.2 \mathrm{ka}$ (Nanson et al., 1995). The Todd and Ross Rivers record major flows between 12.5 and $5 \mathrm{ka}$ (Bourke, 1998) and the streams feeding Lake Lewis show major floods at 11, 8.2 and $7.7 \mathrm{ka}$ (English et al., 2001). In the Great Sandy Desert, regional groundwater tables had risen sufficiently to activate organic sedimentation at Dragon Tree Soak by $7.2 \mathrm{ka}$ (Wyrwoll et al., 1992). At Puritjarra, Poaceae values peaked at $5.8 \mathrm{ka}$, suggesting that the early-mid Holocene climatic optimum in Central Australia is bracketed between 8.3 and $5.8 \mathrm{ka}$.

\section{Late Holocene (4-0 ka)}

Local vegetation was disrupted in the late Holocene with a sharp decline in Poaceae at $3.8 \mathrm{ka}$, coinciding with evidence elsewhere for an abrupt intensification of the El Niño-Southern Oscillation (ENSO) at $4 \mathrm{ka}$ (Shulmeister, 1999), and a weakening of summer monsoon circulation (Marshall and Lynch, 2006; Wyrwoll and Miller, 2001).

Local grasslands recovered over the next two millennia. By $1.5 \mathrm{ka}$ the modern vegetation appears to have become established around Puritjarra, coinciding with a decline in the frequency of ENSO events during the last 1200 a (Moy et al., 2002). Phytolith spectra indicate an open shrubland with abundant grass in the understorey, approximating modern sandhill and spinifex communities in the region today. Leporillus rat middens in the Central Australian ranges record little change in vegetation between 3.8 and 1.6 ka (Berry, 1991; Nelson et al., 1990) but by 800 years ago show that rocky habitats at White Range were also responding to changes in regional rainfall, in this case with an increase in perennial shrub cover (Webeck and Pearson, 2005).

Phytolith spectra for this period consistently show the highest Poaceae values since the last interglacial, suggesting that the last millennium represents the most favourable conditions for human settlement in the desert since the first entry of people into this region. The archaeological record for this period has recently been reviewed (Smith and Ross, 2008), showing strong evidence for regional population growth and expansion of Aboriginal settlement in Central Australia. However, the last 1.5 millennia may also have been marked by increasing seasonal and interannual variability in regional climate. This period saw an increase in the frequency of high-magnitude palaeofloods along the Finke, Todd and Ross Rivers (Pickup et al., 1988; Patton et al., 1993; Bourke, 1998) as well as renewed dune activity in Central Australia (Nanson et al., 1995;
Twidale et al., 2001; Hollands et al., 2006) and further south in the Strzelecki and Tirari Deserts (Fitzsimmons et al., 2007a). Taken as a set, these records suggest a net expansion of summer-rainfall grassland in Central Australia during the last $1500 \mathrm{a}$, with more frequent extreme wet/dry events reflected in episodic dune mobilisation and major floods on Central Australian river systems.

Acknowledgements I wish to thank many colleagues for advice and assistance with this research - the late John Hutton, Joanna Pask, John Prescott and Lins Vellen - and especially John Magee and Doreen Bowdery. Nikki Williams commented on an earlier draft of this paper. The pollen was identified by Jon Luly and the faunal remains by Keryn Walshe and David Ride. Figure 2(B) is reproduced with permission of Geosciences Australia. Figures 3-5 were originally drawn by Win Mumford. An early version of this paper was given at the International Drylands Conference (IGCP413), Upington, South Africa, in 2001.

\section{References}

Barrows TT, Stone JO, Fifield LK, Cresswell RG. 2002. The timing of the last glacial maximum in Australia. Quaternary Science Reviews 21: 159-173.

Berry SL. 1991. The potential of fossil mammal middens as indicators of vegetation history in Central Australia. Australian Journal of Botany 39: 305-313.

Bourke MCA. 1998. Fluvial geomorphology and paleofloods in arid Central Australia. PhD thesis, Australian National University, Canberra.

Bowdery DE. 1995. Phytolith analysis applied to archaeological sites in the Australian arid zone. PhD thesis, Australian National University, Canberra.

Bowdery DE. 1998. Phytolith analysis applied to Pleistocene-Holocene archaeological sites in the Australian arid zone. British Archaeological Reports Series 695, Oxford.

Bowler JM. 1973. Clay dunes: their occurrence, formation and environmental significance. Earth Science Reviews 9: 315-338.

Bowler JM. 1981. Australian salt lakes: a palaeohydrologic approach. Hydrobiologia 82: 431-444.

Brewer R. 1964. Fabric and Mineral Analysis of Soils. Wiley: Sydney.

Chen XY, Prescott JR, Hutton JT. 1990. Thermoluminescence dating on gypseous dunes of Lake Amadeus, central Australia. Australian Journal of Earth Sciences 37: 93-101.

Chen XY, Bowler JM, Magee JW. 1991. Aeolian landscapes in central Australia: gypsiferous and quartz dune environments from Lake Amadeus. Sedimentology 38: 519-538.

Chen XY, Bowler JM, Magee JW. 1993. Late Cenozoic stratigraphy and hydrologic history of Lake Amadeus, a central Australian playa. Australian Journal of Earth Sciences 40: 1-14.

De Deckker P. 2001. Late Quaternary cyclic aridity in tropical Australia. Palaeogeography, Palaeoclimatology, Palaeoecology 170: $1-9$.

English P, Spooner NA, Chappell J, Questiaux DG, Hill NG. 2001. Lake Lewis basin, central Australia: environmental evolution and OSL chronology. Quaternary International 83-85: 81-101.

EPICA Community Members. 2006. One-to-one coupling of glacial climate variability in Greenland and Antarctica. Nature 444: 195198.

Farrand WR. 2001. Sediments and stratigraphy in rockshelters and caves: a personal perspective on principles and pragmatics. Geoarchaeology 16: 537-557.

Fitzpatrick EA. 1984. Micromorphology of Soils. Chapman \& Hall: London.

Fitzsimmons KE, Rhodes EJ, Magee JW, Barrows TT. 2007a. The timing of linear dune activity in the Strzelecki and Tirari Deserts, Australia. Quaternary Science Reviews 26: 2598-2616.

Fitzsimmons KE, Bowler JM, Rhodes EJ, Magee JW. 2007b. Relationships between desert dunes during the late Quaternary in the Lake 
Frome region, Strzelecki Desert, Australia. Journal of Quaternary Science 22: 549-558.

Folk RL. 1971. Longitudinal dunes of the northwestern edge of the Simpson Desert, Northern Territory, Australia. 1. Geomorphology and grain size relationships. Sedimentology 16: 5-54.

Folk RL. 1980. Petrology of Sedimentary Rocks. Hemphill Publishing: Austin, TX.

Hesse PP, Magee JW, van der Kaars S. 2004. Late Quaternary climates of the Australian arid zone: a review. Quaternary International 118119: $87-102$.

Hiscock P. 1994. Technological responses to risk in Holocene Australia. Journal of World Prehistory 8: 267-292.

Hiscock P, Wallis LA. 2005. Pleistocene settlement of deserts from an Australian perspective. In Desert Peoples: Archaeological Perspectives, Veth P, Smith M, Hiscock P (eds). Blackwell: Oxford; 34-57.

Hollands C, Nanson GC, Jones BG, Bristow CS, Price DM, Pietsch TJ. 2006. Aeolian-fluvial interaction: evidence for Late Quaternary channel change and wind-rift linear dune formation in the northwestern Simpson Desert, Australia. Quaternary Science Reviews 25: 142-162.

Jacobson G. 1996. The interrelationship of hydrogeology and landform in central Australia. In Exploring Central Australia: Society, the Environment and the 1894 Horn Expedition, Morton SR, Mulvaney DJ (eds). Surrey Beatty: Chipping Norton, NSW; 249-266.

Jacobson G, Calf GE, Jankowski J, McDonald PS. 1989. Groundwater chemistry and palaeorecharge in the Amadeus basin, Central Australia. Journal of Hydrology 109: 237-266.

Jessop J (ed.) 1981. Flora of Central Australia. Australian Systematic Botany Society and Reed Books: Sydney.

Johnson BJ, Miller GH, Fogel ML, Magee JW, Gagan MK, Chivas AR. 1999. 65,000 years of vegetation change in Central Australia and the Australian summer monsoon. Science 284: 1150-1152.

Lazarides M. 1970. The Grasses of Central Australia. Australian National University Press: Canberra.

Lewis DW. 1984. Practical Sedimentology. Hutchinson Ross: Stroudsburg, PA.

Mabbutt JA. 1977. Desert Landforms: An Introduction to Systematic Geomorphology, Vol. 2 Australian National University Press: Canberra.

Magee JW, Bowler JM, Miller GH, Williams DLG. 1995. Stratigraphy, sedimentology, chronology and palaeohydrology of Quaternary lacustrine deposits at Madigan Gulf, Lake Eyre, South Australia. Palaeogeography, Palaeoclimatology, Palaeoecology 113: 3-42.

Maroulis JC, Nanson GC, Price DM, Pietsch T. 2007. Aeolian-fluvial interaction and climate change: source-bordering dune development over the past 100 ka on Cooper Creek, central Australia. Quaternary Science Reviews 26: 386-404.

Marshall AG, Lynch AH. 2006. Time-slice analysis of the Australian summer monsoon during the late Quaternary using the Fast Ocean Atmosphere model. Journal of Quaternary Science 21: 789-801.

Martin HA. 1973. Palynology and historical ecology of some cave excavations in the Australian Nullarbor. Australian Journal of Botany 21: 283-316.

Martin HA. 1977. Interim report on palynology. In Puntutjarpa Rockshelter and the Australian Desert Culture, Gould RA (ed.). Anthropological Papers of the American Museum of Natural History 54; 165-166.

McWilliam JR, Mison K. 1974. Significance of the $C_{4}$ pathway in Triodia irritans (Spinifex), a grass adapted to arid environments. Australian Journal of Plant Physiology (Functional Plant Biology) 1: $171-175$

Megirian D, Murray PF, Latz PK, Johnson KA. 2002. The Mygoora Local Fauna: a late Quaternary vertebrate assemblage from central Australia. The Beagle: Records of the Museums and Art Galleries of the Northern Territory 18: 77-93.

Miller GH, Fogel ML, Magee JW, Gagan MK, Clarke SJ, Johnson BJ. 2005. Ecosystem collapse in Pleistocene Australia and a human role in megafauna extinction. Science 309: 287-290.

Moy CM, Seltzer GO, Rodbell DT, Anderson DM. 2002. Variability of El Niño/Southern Oscillation activity at millennial timescales during the Holocene epoch. Nature 420: 162-165.

Nanson GC, Price DM, Short SA. 1992. Wetting and drying of Australia over the past $300 \mathrm{ka}$. Geology 20: 791-794.
Nanson GC, Chen XY, Price DM. 1995. Aeolian and fluvial evidence of changing climate and wind patterns during the past $100 \mathrm{ka}$ in the western Simpson Desert, Australia. Palaeogeography, Palaeoclimatology, Palaeoecology 113: 87-102.

Nanson GC, Price DM, Jones BG, Maroulis JC, Coleman M, Bowman H, Cohen TJ, Pietsch TJ, Larsen JR. 2008. Alluvial evidence for major climate and flow regime changes during the middle and late Quaternary in eastern central Australia. Geomorphology 101: 109-129.

Nelson DJ, Webb RH, Long A. 1990. Analysis of stick-nest rat (Leporillus: Muridae) middens from Central Australia. In Packrat Middens: The Last 40,000 Years of Biotic Change, Betancourt JL, Van Devender TR, Martin PS (eds). University of Arizona Press: Tucson, AZ; 428-434.

O'Connor S, Veth P, Campbell C. 1998. Serpent's Glen Rockshelter: report of the first Pleistocene-aged occupation sequence from the Western Desert. Australian Archaeology 46: 12-22.

Patton PC, Pickup G, Price DM. 1993. Holocene palaeofloods of the Ross River, Central Australia. Quaternary Research 40: 201-212.

Petherick LM, McGowan HA, Moss PT, Kamber BS. 2008. Late Quaternary aridity and dust transport pathways in eastern Australia. Quaternary Australasia 25: 2-11.

Perry RA, Lazarides M. 1962. Vegetation of the Alice Springs area. In Lands of the Alice Springs Area, Northern Territory, 1956-57, Perry RA (ed.). Commonwealth Scientific and Industrial Research Organisation: Melbourne; 208-236.

Pickup G, Allan G, Baker VR. 1988. History, palaeochannels and palaeofloods of the Finke River, Central Australia. In Fluvial Geomorphology of Australia, Warner RF (ed.). Academic Press: Sydney; 177-200.

Prescott JR, Williams FM, Hunt CD. 2007. Comparison of TL multiple aliquot, single grain GLSL SAR and C-14 ages for the Puritjarra, Australia, rock shelter. Quaternary Geochronology 2: 344-349.

Racek AA. 1969. The freshwater sponges of Australia (Porifera: Spongillidae). Australian Journal Marine and Freshwater Research 20: 267-310.

Rosenfeld A, Smith MA. 2002. Rock-art and the history of Puritjarra rock shelter, Cleland Hills, Central Australia. Proceedings of the Prehistoric Society 68: 103-124.

Ross J. 2003. Rock art, ritual and relationships: an archaeological analysis of rock art from the Central Australian arid zone, $\mathrm{PhD}$ thesis. University of New England, Armidale, NSW.

Rust BR, Nanson GC. 1989. Bedload transport of mud as pedogenic aggregates in modern and ancient rivers. Sedimentology 36: 291306.

Shulmeister J. 1999. Australasian evidence for mid-Holocene climate change implies precessional control of Walker Circulation in the Pacific. Quaternary International 57/58: 81-91.

Singh G, Luly J. 1991. Changes in vegetation and seasonal climate since the last full glacial at Lake Frome, South Australia. Palaeogeography, Palaeoclimatology, Palaeoecology 84: 75-86.

Smith MA. 1987. Pleistocene occupation in arid Central Australia. Nature 328: 710-711.

Smith MA. 1989. The case for a resident human population in the Central Australian Ranges during full glacial aridity. Archaeology in Oceania 24: 93-105.

Smith MA. 2004. The grindstone assemblage from Puritjarra rock shelter: investigating the history of seed-based economies in arid Australia. In Archaeology from Australia, Murray T (ed.). Australian Scholarly Publishing: Melbourne; 168-186.

Smith MA. 2005a. 'Peopling' the Cleland Hills: Aboriginal history in western central Australia, 1850-1980. Aboriginal History Monograph 12. Aboriginal History Inc., Canberra.

Smith MA. 2005b. Moving into the Southern Deserts: an archaeology of dispersal and colonisation. In $23^{\circ} \mathrm{S}$ : Archaeology and Environmental History of the Southern Deserts, Smith MA, Hesse P (eds). National Museum of Australia Press: Canberra; 92-107.

Smith MA. 2006. Characterising Late Pleistocene and Holocene stone artefact assemblages from Puritjarra rock shelter: a long sequence from the Australian desert. Records of the Australian Museum 58: $371-410$.

Smith MA, Ross JA. 2008. What happened at 1500-1000 BP in Central Australia? Timing, impact and archaeological signatures. The Holocene 18: 379-388. 
Smith MA, Vellen L, Pask J. 1995. Vegetation history from archaeological charcoals in central Australia: the late Quaternary record from Puritjarra rock shelter. Vegetation History and Archaeobotany 4: 171-177.

Smith MA, Prescott JR, Head MJ. 1997. Comparison of ${ }^{14} \mathrm{C}$ and luminescence chronologies at Puritjarra rock shelter, Central Australia. Quaternary Science Reviews (Quaternary Geochronology) 16: 299320.

Smith MA, Fankhauser B, Jercher M. 1998a. The changing provenance of red ochre at Puritjarra rock shelter, Central Australia: Late Pleistocene to present. Proceedings of the Prehistoric Society 64: 275292.

Smith MA, Vellen L, Pask J. 1998b. SEM photomicrographs of central Australian wood charcoals: a guide to the identification of archaeological and fossil charcoals. In Identifying Wood Charcoal Remains as Palaeo Evidence for Regions of Central and Northeast Australia, Hope G (ed.). Australian National University, Canberra. Research Papers in Archaeology and Natural History 28; 5-63.

Smith MA, Bird MI, Turney CSM, Fifield LK, Santos GM, Hausladen PA, di Tada ML. 2001. New ABOX AMS $-{ }^{14} \mathrm{C}$ ages remove dating anomalies at Puritjarra rock shelter. Australian Archaeology 53: $45-47$.

Smith MA, Watchman A, Ross J. 2009. Direct dating indicates a midHolocene age for archaic rock engravings in arid Central Australia. Geoarchaeology 24: 191-203.

Thackway R, Cresswell ID. 1995. An interim biogeographic regionalisation for Australia. Australian Nature Conservation Agency, Canberra.

Thorley PB. 1998. Pleistocene settlement in the Australian arid zone: occupation of an inland riverine landscape in the central Australian ranges. Antiquity 72: 34-45.

Tooth S. 1997. The morphology, dynamics and Late Quaternary sedimentary history of ephemeral drainage systems on the northern plains of Central Australia. PhD thesis, University of Wollongong, Wollongong, NSW.
Twidale CR, Prescott JR, Bourne JA, Williams FM. 2001. Age of desert dunes near Birdsville, southwest Queensland. Quaternary Science Reviews 20: 1355-1364.

van der Kaars S, De Deckker P. 2002. A late Quaternary pollen record from deep-sea core Fr10/95 GC17 offshore Cape Range peninsula, northwestern Western Australia. Review of Palaeobotany and Palynology 120: 17-39.

Veth PM. 1993. Islands in the interior: The dynamics of prehistoric adaptations within the arid zone of Australia. International Monographs in Prehistory, Archaeology Series 3, Ann Arbor, MI.

Veth P. 1995. Aridity and settlement in northwest Australia. Antiquity 265: 733-746.

Veth P. 2005. Cycles of aridity and human mobility: risk minimization among late Pleistocene foragers of the western Desert, Australia. In Desert Peoples: Archaeological Perspectives, Veth P, Smith M, Hiscock P (eds). Blackwell: Oxford; 100-115.

Wallis LA. 2001. Environmental history of northwest Australia based on phytolith analysis at Carpenter's Gap 1. Quaternary International 8385: 103-117.

Webeck K, Pearson S. 2005. Stick-nest rat middens and a late-Holocene record of White Range, central Australia. The Holocene 15: 466471.

Woodward JC, Goldberg P. 2001. The sedimentary records in Mediterranean rockshelters and caves: archives of environmental change. Geoarchaeology 16: 327-354.

Wright R. 1992. Doing Multivariate Archaeology and Prehistory: Handling Large Data Sets with MV-ARCH, (2nd edn). MV-Arch: Sydney.

Wyrwoll K-H, Miller GH. 2001. Initiation of the Australian summer monsoon 14,000 years ago. Quaternary International 83-85: 119128.

Wyrwoll K-H, Hopwood J, McKenzie NL. 1992. The Holocene palaeohydrology and climatic history of the northern Great Sandy DesertFitzroy Trough: with special reference to the history of the northwest Australian monsoon. Climatic Change 22: 47-65. 